\title{
Audiology
}

Neurotology

\section{New Concepts in Electrical Stimulation in Vestibular Dysfunction}

Guest Editors

Angel Ramos Macias, Las Palmas

Sharon Cushing, Toronto, ON

Nicolás Pérez, Madrid 


\section{Sponsored by the European Union's Horizon 2020 Research and Innovation Programme under Grant Agreement No. 801127}

\section{S. Karger}

Medical and Scientific Publishers

Basel $\cdot$ Freiburg $\cdot$ Hartford $\cdot$ Oxford Bangkok $\cdot$ Dubai $\cdot$ Kuala Lumpur . Melbourne $\cdot$ Mexico City

Moscow $\cdot$ New Delhi $\cdot$ Paris . Shanghai $\cdot$ Tokyo

\section{Disclaimer}

The statements, opinions and data contained in this publication are solely those of the individual authors and contributors and not of the publisher and the editor(s). The appearance of advertisements in the journal is not a warranty, endorsement, or approval of the products or services advertised or of their effectiveness, quality or safety. The publisher and the editor(s) disclaim responsibility for any injury to persons or property resulting from any ideas, methods, instructions or products referred to in the content or advertisements.

Drug Dosage

The authors and the publisher have exerted every effort to ensure that drug selection and dosage set forth in this text are in accord with current recommendations and practice at the time of publication. However, in view of ongoing research, changes in government regulations, and the constant flow of information relating to drug therapy and drug reactions, the reader is urged to check the package insert for each drug for any change in indications and dosage and for added warnings and precautions. This is particularly important when the recommended agent is a new and/or infrequently employed drug.
All rights reserved.

No part of this publication may be translated into other languages, reproduced or utilized in any form or by any means, electronic or mechanical, including photocopying, recording microcopying, or by any information storage and retrieval system, without permission in writing from the publisher or in the case of photocopying, direct payment of a specified fee to the Copyright Clearance Center (see "General Information")

\section{Copyright:}

Open Access

agreement with European Consortium research group under the auspices of the European Commission (Horizon2020 Fet Open: Project: European Development of Bionic Vestibular Implant For Bilateral Vestibular Dysfunction. Grant Agreement No: 801127 . Project Acronym: Bionic \VEST), and related research groups

(C) 2019/2020 The Author(s) Published by S. Karger AG, Basel P.O. Box, CH-4009 Basel (Switzerland)

Printed on acid-free and non-aging paper (ISO 9706)

ISBN 978-3-318-06681-4

e-ISBN 978-3-318-06682-1

\section{KARGER}




\section{Audiology Neurotology}

\section{Contents}

Editorial

5 New Concepts in Electrical Stimulation in Vestibular Dysfunction Harris, J.P. (La Jolla, CA)

Reviews

6 Electrical Vestibular Stimulation in Humans: A Narrative Review Sluydts, M. (Wilrijk); Curthoys, I. (Sydney, NSW); Vanspauwen, R. (Wilrijk); Papsin, B.C.; Cushing, S.L. (Toronto, ON); Ramos, A.; Ramos de Miguel, A.; Borkoski Barreiro, S. (Las Palmas of Gran Canaria); Barbara, M. (Rome); Manrique, M. (Pamplona); Zarowski, A. (Wilrijk)

25 Concepts and Physiological Aspects of the Otolith Organ in Relation to Electrical Stimulation

Curthoys, I.S. (Sydney, NSW)

35 The Superiority of the Otolith System

Ramos de Miguel, A. (Las Palmas de Gran Canaria); Zarowski, A.; Sluydts, M. (Wilrijk); Ramos Macias, A. (Las Palmas de Gran Canaria); Wuyts, F.L. (Antwerp)

42 Correlation between High-Resolution Computed Tomography Scan Findings and Histological Findings in Human Vestibular End Organs and Surgical Implications

Manrique-Huarte, R.; Zulueta-Santos, C.; Garaycochea, O.; Alvarez Linera-Alperi, M.; Manrique, M. (Pamplona)

Original Papers

50 Early Assessment of Vestibular Function after Unilateral Cochlear Implant Surgery

Barbara, M.; Talamonti, R.; Benincasa, A.T.; Tarentini, S.; Filippi, C.; Covelli, E.; Monini, S. (Rome)

60 BalanCl: Head-Referenced Cochlear Implant Stimulation Improves Balance in Children with Bilateral Cochleovestibular Loss

Wolter, N.E.; Gordon, K.A.; Campos, J.L. (Toronto, ON); Vilchez Madrigal, L.D. (San Jose); Pothier, D.D. (Toronto, ON); Hughes, C.O. (London); Papsin, B.C.; Cushing, S.L. (Toronto, ON)

72 Bilateral Vestibular Hypofunction in the Time of the Video Head Impulse Test

Pérez-Fernández, N. (Madrid); Alvarez-Gomez, L.; Manrique-Huarte, R. (Pamplona) 
79 Chronic Electrical Stimulation of the Otolith Organ: Preliminary Results in Humans with Bilateral Vestibulopathy and Sensorineural Hearing Loss Ramos Macias, A.; Ramos de Miguel, A.; Rodriguez Montesdeoca, I.; Borkoski Barreiro, S.; Falcón González, J.C. (Las Palmas)

91 Restoring the High-Frequency Dynamic Visual Acuity with a Vestibular Implant Prototype in Humans

Starkov, D. (Maastricht/Tomsk); Guinand, N. (Geneva); Lucieer, F. (Maastricht); Ranieri, M.; Cavuscens, S. (Geneva); Pleshkov, M. (Maastricht/Tomsk); Guyot, J.-P. (Geneva); Kingma, H. (Maastricht/Tomsk); Ramat, S. (Pavia); Perez-Fornos, A. (Geneva); van de Berg, R. (Maastricht/Tomsk)

96 Interactions between Auditory and Vestibular Modalities during Stimulation with a Combined Vestibular and Cochlear Prosthesis Phillips, J.O.; Ling, L.; Nowack, A.; Rebollar, B.; Rubinstein, J.T. (Seattle, WA)

109 Author Index

110 Subject Index 